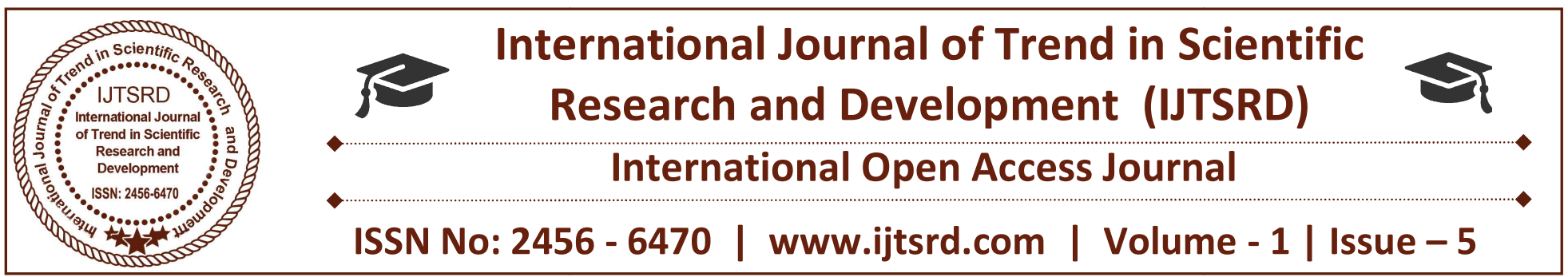

\title{
Nehru and Indian Foreign Policy
}

\author{
Hasina Jabeen \\ Research Scholar \\ Jiwaji Unversity Gwalior (M.P)
}

\author{
Mohd Azhar Ud Din Malik \\ Research Scholar \\ Jiwaji Unversity Gwalior (M.P)
}

\section{ABSTRACT}

Nehru was one of the influencing statesman of 20th century. He played a great role in the freedom struggle of India. Nehru is mentor of Indian foreign policy and provide India a precise scheme of thought with regard to look their action in specific matters concerning international relation. Nehru was the critic of American imperialism, colonial exploitation and racial discrimination. Nehru had a decisive influence on the foreign policy.

Keywords: struggle, foreign policy, international relation, imperialism, colonialism

\section{Introduction}

Nehru had a great interest in international affairs and thought that India should make its stand Clear on crucial global issues. Nehru made a great contribution through his speeches and writings in which he stated that India should have interest in global issues. He opposed to put down the nationalistic aspirations of other people. Nehru foresaw the emergence of new imperialistic powers especially U.S. imperialism. Nehru said that India should declare unequivocally that she would be no partly to any war without her consent and if she is bullied into such a war she would not heap any way.

\section{Objectives}

1. To analyze the impact of Nehru foreign policy.

2. To know the impact of foreign policy on international relations.

\section{Research Methodology}

This paper is basically descriptive and analytic in nature. The data used is purely secondary according to the need of study.

\section{Contribution of Nehru to Indian foreign policy}

When Nehru became its prime minister in September 1946 he informed the world that India would develop an active role in world affairs, this statement brought a confusion in international politics because his statement appeared to be a bit vague. The approach of Nehru could be easily observed from the foreign policy evolved during the period of freedom struggle. Nehru's policy had positive effect on the economic development of country. Nehru always played a great role to promote world peace and international understanding. In 1958 Nehru himself confessed that he was not architect of Indian foreign policy but drew counters of the foreign policy by declaring that India would always keep away from the power politics. He was a man of great foresight and his policy of nonalignment remained continue despite its conflict with China and Pakistan.

\section{Policy of Non- Alignment}

Policy of non- alignment was started by Nehru, embodied the heritage of the long Indian struggle for freedom and was not something contrived in haste on the marrow of independence because of India's military weakness or its being new in the field of diplomacy. Nehru predicted in non-alignment a guarantee of India's independence in the field of foreign policy. 


\section{Nehru's role in Commonwealth}

Nehru's decision keeping is one of most positive point for the country, and India got its membership in Commonwealth. It transferred the character of Commonwealth. As a result, the powerful British Empire underwent a change in its composition, legal position, conception and formation. India become the first nonwhite member of Commonwealth along with Pakistan. It changed the whole scenario. Today this truth is acceptable that Nehru's decision created the new Commonwealth and helped to enlarge its area.

\section{Nehru and Panchsheel}

Panchsheel constitutes a major feature and principle of the foreign policy of India. Pandit Nehru, who is known as the main architect of the foreign policy of India and an apostle of peace firmly, believed that if the nations of the world accepted some code of conduct, wars could be prevented. War cannot be considered as an instrument of foreign policy. He believed that war was an obsolete and futile, irrelevant and inconsistent with the humanity. It was in human, ridiculous and irrelevant to talk of war. As Nehru said; "I think that the biggest idea that has gradually evolved in people's minds all over the world is the futility of war, that war does not solve any major issues and that therefore all problems, however difficult and intricate, should be approached peacefully and this heralds an entirely new approach all over the world". Nehru considered Panchsheel as a principle applicable to a particular context. There was nothing new about applying it to some particular situation and solve the problems peacefully was India's contribution. Panchsheel implies five principles of peaceful coexistence, which were first formulated in the preamble to the agreement between India and China in regard to Tibet, which was signed on April 29, 1954, the five principles were said to be

1. Mutual respect for each other's territorial integrity and Sovereignty,

\section{Mutual non-aggression,}

3. Mutual non-interference in each other's internal affairs,

\section{Equally and mutual benefit,}

The principles, it was believed that, would lay the foundation for the pattern of future world peace, Mr. Chou-en-lai, Prime Minister of China visited India in 1954 and agreed to Mr. Nehru on their joint statement and affirmed the five principles of India-Chinese agreement on Tibet. Both the leaders recognized the different social and political systems existed in various parts of Asia and the world. And they made recourse to Panchsheel as the guiding principle to maintain co-ordinal and peaceful relations and to create durable peace both in Asia and the world.

\section{Conclusion}

Nehru was a man of great vision. He promotes peace throughout the world. He prompted relationship in a peaceful environment. He promoted relationship with other countries in peaceful way to make the country economically developed. He was a man of principles who only believed in peaceful means.

\section{References}

1) Indira Gandhi, "Foreword," Selected Works of Jawaharlal Nehru, Second Series, Vol.I, (New Delhi, Vikas Publishing House, 1984).

2) The Collected Works of Mahatma Gandhi (New Delhi, The Publication Division, Ministry of Information \& Broadcasting, Govt, of India, 1969).

3) "India and the Need for International Contacts," Selected Works of Jawaharlal Nehru, Vol.3, (New Delhi, Teen Murthy House, 1972).

4) Sarvepalli Gopal, Jaxoaharlal Nehru: A Biography, Part I, (New Delhi, Oxford University Press, 1976).

5) Sarvepalli Gopal, J.Nehru: A Biography, (London, Oxford, Vol.II).

6) Foreign Affairs: 'India Friends and Neighbours, William j.Barnads.

7) Gopal, S., Jawaharlal Nehru: A Biography, Vol.I, (Delhi, Oxford University Press, 1984).

8) Sir W. Ivor Jenings, Problems ofthe New Commomvealth (North Carolina, Duke University Press, 1958).

\section{Peaceful co-existence.}

